\title{
Effects of enzymatically hydrolyzed fish by- products in diet of juvenile rainbow trout (Oncorhynchus mykiss)
}

\author{
Jinho Bae', Abul Kalam Azad², Seonghun Won', Ali Hamidoghli', Minji Seong ${ }^{1}$ and Sungchul C. Bai ${ }^{1 *}$ (D)
}

\begin{abstract}
Five experimental diets were formulated to evaluate the effects of dietary enzymatically hydrolyzed tuna by-product on growth, non-specific immune responses, and hematology of juvenile rainbow trout (Oncorhynchus mykiss). A basal diet with $50 \%$ of fishmeal was used as control (CON) and four other diets replaced 12.5\% (TBB 12.5$), 25 \%$ ( $\mathrm{TBB}_{25}$ ), 37.5\% $\left(\mathrm{TBB}_{37.5}\right)$, and $50 \%$ ( $\left.\mathrm{TBB}_{50}\right)$ of fish meal in the $\mathrm{CON}$ diet. Juvenile rainbow trout $(4.87 \pm 0.05 \mathrm{~g})$ were randomly distributed into 15 tanks $(50 \mathrm{~L})$ and fed 3-4\% of wet body weight two times a day. At the end of 7 weeks of feeding trial, weight gain, specific growth rate, feed efficiency, and protein efficiency ratio of fish fed CON diet were significantly higher than those of fish fed $\mathrm{TB}_{50}$ diet $(P<0.05)$. But there were no significant differences among fish fed $\mathrm{CON}, \mathrm{TBB}_{12.5}, \mathrm{TBB}_{25}$, and $\mathrm{TBB}_{37.5}$ diets $(P>0.05)$. There were no significant differences in GPT levels among fish fed $C O N$, $\mathrm{TBB}_{12.5}, \mathrm{TBB}_{25}$, and $\mathrm{TBB}_{37.5}$ diets. Also, there were no significant differences in lysozyme, superoxide dismutase, glucose, and total protein levels in all experimental diet $(P>0.05)$. The broken-line analysis indicated that the minimum dietary level of enzymatically hydrolyzed tuna by-product to replace fishmeal could be $29.7 \%$ in rainbow trout. These results indicated that the optimum level of dietary enzymatically hydrolyzed tuna by-product could replace greater than $29.7 \%$ but less than $37.5 \%$ of fishmeal in juvenile rainbow trout diet.
\end{abstract}

Keywords: Rainbow trout, Enzymatic hydrolysis, Growth performance, Immune response, Tuna by-products

\section{Background}

Fish meal (FM) is the one of the most important ingredients used in aquafeed. FM is a high-quality source of protein and is desirable for its rich essential amino acids profile (Cho and Kim 2011; Anderson et al. 2016) as well as for its vitamin and mineral content (IFOMA 2000). Typically, FM (66\% crude protein) is the preferred source of protein in aquafeed formulation, yet the cost of FM is continually increasing (Tomas et al. 2005; Anderson et al. 2016; FAO 2018). It is to be noted that the world demand of FM increased by only about $27 \%$ during the past two decades, while FM output by the major FM-producing countries actually decreased. Because of the limited supply of FM coupled with its increasing demand, the cost of producing fish is likely to

\footnotetext{
* Correspondence: scbai@pknu.ac.kr

${ }^{1}$ Department of Marine Bio-Materials and Aquaculture/Feeds and Foods Nutrition Research Center (FFNRC), Pukyong National University, 599-1 Daeyeon 3-Dong, Busan 608-737, Republic of Korea

Full list of author information is available at the end of the article
}

increase. According to a recent report, the global production of fish meal has decreased by about 1.1 million tons compared to the production in 2000 (IFFO 2018). Tremendous price increases for FM together with environmental concerns have forced the aquaculture industry to find alternative protein sources for aquafeed formulation. As a result, at this moment, the replacement of FM in aqua feeds is one of the most pressing issues facing the industry. Conversely, alternative protein sources can relieve this problem by lowering the cost of feed, reducing the amount of dependence on wild fish, and potentially reduces the nutrient levels in effluent waste (Van Weerd et al. 1999; Papatryphon and Soares Jr. 2001; Masumoto et al. 2001). However, for most species, there is a limit on amount of FM that can be replaced by alternative protein sources without causing negative effects on the health and physiology of the fish. Therefore, a new feed ingredient that is both cheaper and free from disease is highly desirable. Therefore, fishery by-products could be a possible solution. Uyan et al. (2006) reported that 
tuna muscle by-product powder is a promising feed ingredient to replace $50 \%$ FM protein without reduction in the growth performance of olive flounder.

Enzymatic hydrolysis is a process by which enzymes facilitate the cleavage of chemical bonds by water, playing a pivotal role in the digestion of food (Nielsang et al. 2005). This process makes it possible to improve the nutritive value of individual feed ingredients (PER, digestibility and FCR). Moreover, the moisture contents of the ingredients remain almost the same, varying only by 2.5 $\pm 4.4 \%$, maintaining typical parameters for storage of ingredients. Lastly, an important benefit of extrusion after enzymatic hydrolysis is the sterilization of the ingredients. Enzymatic hydrolyzed by-products are now widely used to modify or improve protein quality and their digestibility (Panyam and Kilara 1996; Liaset et al. 2000; Je et al. 2007; Baek and Cadwallader 1995; Nielsang et al. 2005). Nevertheless, the presence of endogenous enzymes in by-products may induce auto hydrolysis. In the case of squid gut and muscle, high endogenous proteolytic activity has been reported (Sugiyama et al. 1989; Leblanc and Gill 1982; Rodger et al. 1984) and during chopping, the tissues become hydrolyzed, rendering it richer in free essential amino acids (Lian et al. 2005). Hydrolyzed fish by-products from Alaskan fisheries have been evaluated for replacement of menhaden FM in Litopenaeus vannamei diets (Forster et al. 2011). Replacement of FM in aqua feeds with inexpensive protein sources, such as unexploited by-products which are regionally or locally available, may be a great opportunity for sustainable resource utilization.

Rainbow trout, Oncorhynchus mykiss, is one of most popular fish species around the world, due to its excellent meat quality (Vehviläinen et al. 2008). It is also one of the most studied species and is widely used for research in many fields such as carcinogenesis, toxicology, immunology, ecology, physiology, and nutrition (Thorgaard et al. 2002; Cowey 1992; Boyle et al. 2013; Berthelot et al. 2014). Global rainbow trout production from aquaculture has grown tremendously and has reached 814,090 metric tons as of 2016 (FAO 2018). For Republic of Korea, rainbow trout is also one of the commercially important freshwater species with 3358 metric tons of production in 2017; ranking third among freshwater species nationally (KOSTAT 2018). Numerous studies have been conducted on FM replacement in rainbow trout (Hauptman et al. 2014). However, to our knowledge, no study has been conducted using enzymatically hydrolyzed tuna by-products for replacing FM in the diet of juvenile rainbow trout. Based on the results obtained in previous studies, the aim of this study is to partially replace FM with enzymatically hydrolyzed tuna by-products in order to examine the effects on growth and non-specific immune responses in juvenile rainbow trout.

\section{Materials and methods}

\section{Experimental design and diets}

A basal diet was formulated containing crude protein $50.22 \%$, crude lipid $13.71 \%$, ash $9.79 \%$, and moisture 4.93\%; without inclusion of enzymatically hydrolyzed tuna backbone by-products, used as control diet (CON) and four other experimental diets were formulated using enzymatically hydrolyzed tuna backbone by-products. $\mathrm{TBB}_{12.5}, \mathrm{TBB}_{25}, \mathrm{TBB}_{37.5}$, and $\mathrm{TBB}_{50}$ diet were formulated with hydrolyzed tuna by-products level of $12.5 \%, 25 \%$, $37.5 \%$, and $50 \%$ replacement of FM respectively (Table 1 ). The ingredients were grounded into powder form using a grinding machine and sieved before inclusion of ingredients. The resultant mixtures become pelletized with a pellet machine with no heating using a module of 2-mm diameter and air dried for 3 days. The dried feeds were

Table 1 Formulation and proximate composition of five experimental diets (\% of dry matter basis)

\begin{tabular}{|c|c|c|c|c|c|}
\hline \multirow{2}{*}{$\begin{array}{l}\text { Ingredients } \\
\text { (\% in diet) }\end{array}$} & \multicolumn{5}{|l|}{ Diets $^{a}$} \\
\hline & CON & $\mathrm{TBB}_{12.5}$ & $\mathrm{TBB}_{25}$ & $\mathrm{TBB}_{37.5}$ & $\mathrm{TBB}_{50}$ \\
\hline Fishmeal & 50 & 43.75 & 37.50 & 31.25 & 25.00 \\
\hline En. H.B ${ }^{b}$ & 0.00 & 5.82 & 11.64 & 17.46 & 23.27 \\
\hline Blood meal & 2.90 & 2.90 & 2.90 & 2.90 & 2.90 \\
\hline Soybean meal & 3.50 & 3.50 & 3.50 & 3.50 & 3.50 \\
\hline Wheat gluten meal & 7.9 & 7.9 & 7.9 & 7.9 & 7.9 \\
\hline Cornstarch & 0.00 & 0.6 & 1.18 & 1.78 & 2.39 \\
\hline Wheat flour & 20.00 & 20.00 & 20.00 & 20.00 & 20.00 \\
\hline Soybean oil & 7.80 & 7.80 & 7.80 & 7.80 & 7.80 \\
\hline Fish oil & 3.37 & 3.02 & 2.68 & 2.33 & 1.98 \\
\hline Cellulose & 0.53 & 0.71 & 0.90 & 1.08 & 1.26 \\
\hline Vitamin premix & 2.00 & 2.00 & 2.0 & 2.00 & 2.00 \\
\hline Mineral premix & 2.00 & 2.00 & 2.0 & 2.00 & 2.00 \\
\hline Total & 100 & 100 & 100 & 100 & 100 \\
\hline \multicolumn{6}{|c|}{ Proximate analysis (\% of DM) } \\
\hline Moisture & 4.93 & 5.72 & 6.17 & 7.22 & 7.30 \\
\hline Protein & 50.22 & 48.71 & 48.34 & 47.95 & 46.81 \\
\hline Lipid & 13.71 & 12.75 & 14.89 & 14.25 & 13.61 \\
\hline Ash & 9.79 & 9.59 & 9.49 & 9.11 & 9.05 \\
\hline
\end{tabular}

TBB12.5 tuna backbone by-products at 12.5\% FM replacement (Samhae Company, Gyeongiu, South Korea)

TBB25 tuna backbone by-products at 25\% FM replacement (Samhae Company, Gyeongiu, South Korea)

TBB37.5 tuna backbone by-products at 37.5\% FM replacement (Samhae Company, Gyeongiu, South Korea)

TBB50 tuna backbone by-products at 50\% FM replacement

${ }^{a} \mathrm{CON}$ control diet (the basal diet)

${ }^{b}$ En. H.B enzymatic hydrolyzed by-products (Samhae Company, Gyeongiu, South Korea) 
sieved and packaged in zip-lock bags, labeled and stored at $-20^{\circ} \mathrm{C}$ until the feeding trial.

\section{Experimental fish and feeding conditions}

The feeding trial was conducted in the Department of Marine Bio-Materials and Aquaculture and Feeds and Foods Nutrition Centre, Pukyong National University (PKNU), Busan, Republic of Korea. Experimental rainbow trout fry were collected from a local rainbow trout farm named Ihwajeong Fish Farm, Sangju city, Korea. Before starting of the feeding trial, all fishes were fed with the basal diet two times in a day to acclimatize them to the laboratory experimental conditions for 2 weeks. Feeding trial was done using an indoor semi-recirculation system with 15 tanks of $50 \mathrm{~L}$ water holding capacity receiving constant filtered freshwater flow at a rate of $2 \mathrm{~L} \mathrm{~min}^{-1}$ from the central tank. Half of the water was exchanged everyday by pumping filtered fresh water to the central tank. Supplementary continuous aeration facility provided to maintain required dissolved oxygen (D.O) and by using water heaters, temperature always maintained at $14.0 \pm 0.1{ }^{\circ} \mathrm{C}$ throughout the experimental period. Four hundred eighty fishes with an average weight of $4.87 \pm 0.05 \mathrm{~g}$ (mean $\pm \mathrm{SD}$ ) were weighed and distributed as 20 fish/tank randomly into the 15 experimental indoor tanks. Three tanks were randomly selected for each one of the experimental diet. In this way, 15 tanks are randomly assigned for 5 dietary treatments and marked the tanks. Feeding was done two times daily (09:00 A.M. and 05:00 P.M.). Feed amount adjusted ranged from 3 to $4 \%$ according to the wet body weight in the beginning and at the end of feeding trial respectively for 7 weeks. Two hours after feeding, all tanks were siphoned to remove fecal matter and uneaten feeds daily. Mortality would check daily, dead fish immediately removed and weighed, and required feed amounts for the tanks adjusted according to the remaining body weight of fish in the tanks. Dead fish was not replaced during the experiment. Total weight of fish in each tank was determined at 4th week for adjust the amount of diet for feeding. Before each checking, fish were starved for $24 \mathrm{~h}$ to avoid inclusion of ingested feed in the measurements of fish body weight as well as to minimize stress.

\section{Sample collection and analysis}

After completion of the feeding trial, all fish were counted and weighed in each tank to calculate weight gain (WG), specific growth rate (SGR), feed efficiency (FE), protein efficiency ratio (PER), and survival rate (SR). From each tank, three fish were randomly selected, measurement of length, weight, and dissected to obtain visceral mass and liver to calculate hepatosomatic indices (HSI), viscerosomatic indices (VSI), and condition factor (CF). Blood samples were collected from the caudal vein of the fish with $1 \mathrm{ml}$ syringes. Serum samples obtained from blood on clotting by centrifugation at $5000 \times g$ for $10 \mathrm{~min}$ and stored at $-70{ }^{\circ} \mathrm{C}$ for the analysis of the activities of lysozyme and superoxide dismutase (SOD). A turbid metric assay was used for the measurement of lysozyme activity of blood serum using the method by Hultmark (1980) with slightly modifications. Micrococcus lysodeikticus $\left(0.75 \mathrm{mg} \mathrm{ml}^{-1}\right)$ was suspended in sodium phosphate buffer (0.1 M, pH 6.4), then $200 \mu \mathrm{l}$ of suspension was placed in each well of 96-well plates and after that $20 \mu \mathrm{l}$ of test serum was added. After incubation, the reduction in absorbance of the samples was recorded at $570 \mathrm{~nm}$ at room temperature for 0 and $60 \mathrm{~min}$ in a micro plate reader (UVM 340, Biochrom, Cambridge, UK). One unit of lysozyme activity was regarded as a reduction in absorbance of $0.001 \mathrm{~min}^{-1}$.

Activity of SOD was measured according to the percentage of reaction inhibition rate of the enzyme with WST-1 (water-soluble tetrazolium dye) substrate and xanthine oxidase using an SOD Assay Kit (Enzo ADI-900-157, Enzo Life Sciences, Inc.) in accordance with manufacturer's instructions. Each endpoint assay was monitored by absorbance at $450 \mathrm{~nm}$ (the absorbance wavelength for the colored product of WST-1 reaction with superoxide) after 20 min of reaction time at $37^{\circ} \mathrm{C}$. The inhibition percentage was normalized by $\mathrm{mg}$ of protein and showed as SOD activity units. Serum portions were also used for the biochemical parameters analysis of total protein (TP) of plasma, glutamic oxaloacetic transaminase (GOT), glutamic pyruvic transaminase (GPT), and glucose activities determined using the commercial clinical kits of Fuji DRI-CHEM 3500i, Fuji Photo Film Ltd., Tokyo, Japan.

From each tank, three fish were collected and pooled together according to the fish fed with different experimental diets; homogenized and freeze-dried at $-80^{\circ} \mathrm{C}$ for analysis. Proximate compositions of the experimental fish and the basal diet were determined according to standard procedures of AOAC (2005) in duplicates. Both samples were dried at $105{ }^{\circ} \mathrm{C}$ to a constant weight to determine moisture content. Determination of ash content was done by incineration in a muffle furnace at $550{ }^{\circ} \mathrm{C}$ for $3.5 \mathrm{~h}$, crude lipid was determined by the Soxhlet extraction using Soxtec system 1046 (Tecator AB, Foss, Hoganas, Sweden) and crude protein by the Kjedahl method $(\mathrm{N} \times 6.25)$ after acid digestion. Laboratory analyses were done at the Feeds and Foods Nutrition Research Centre (FFNRC) at Yongdang campus of PKNU, Republic of Korea.

\section{Statistical analysis}

After completion of all laboratory analysis, all data were analyzed by the one-way analysis of variance (ANOVA) 
using SAS Program, Version 9.1 (SAS Institute, Cary, NC, USA) to test for the effects of the different dietary experimental treatments. A least significant difference (LSD) test was used to compare the means of significant effect. Effects of treatments were considered significant at confidence level of $P<0.05$. For each treatment, mean and SD were also calculated.

\section{Results}

\section{Growth performances}

Growth performances of juvenile rainbow trout, Oncorhynchus mykiss, based on weight gain (WG), specific growth rate (SGR), feed efficiency (FE), protein efficiency ratio (PER), and survival rate (SR) fed with five different experimental diets for 7 weeks are summarized in Table 2. After completion of feeding trial, WG, SGR, FE, and PER of fish fed $\mathrm{CON}$ was significantly higher than fish fed $\mathrm{TBB}_{50}$ diet $(P<0.05)$. But there were no significant differences $(P>0.05)$ between fish fed $\mathrm{TBB}_{12.5}, \mathrm{TBB}_{25}$, and $\mathrm{TBB}_{37.5}$ diets. Broken-line model analysis on the basis of WG indicated that the minimum dietary level of enzymatic hydrolyzed of tuna backbone by-product to replace fishmeal could be up to $29.7 \%$ in rainbow trout (Fig. 1). Survival rate varied from 91.67 to $95.67 \%$, but no significant difference $(P>0.05)$ was found among fish fed with all dietary treatments. There was no significant difference in hepatosomatic index (HSI). Viscerosomatic index (VSI) of fish fed $\mathrm{TBB}_{37.5}$ was significantly higher than fish fed $\mathrm{TBB}_{50}$ diet. But no significant difference was found among the fish fed $\mathrm{CON}, \mathrm{TBB}_{12.5}$, and $\mathrm{TBB}_{25}$ diets. $\mathrm{CF}$ of $\mathrm{CON}$ was significantly higher than $\mathrm{TBB}_{12}$ and $\mathrm{TBB}_{50}$ diets. But no significant difference was found among the fish fed $\mathrm{TBB}_{25}$ and $\mathrm{TBB}_{37.5}$ diets.

\section{Non-specific immune responses}

Non-specific immune responses based on lysozyme and superoxide dismutase (SOD) activities of juvenile rainbow trout fed with five different experimental diets for 7 weeks are summarized in Table 3 . In lysozyme activity and superoxide dismutase, no significant differences were found among the fish fed every experimental groups $(P<0.05)$.

\section{Whole body proximate analysis}

Whole body proximate compositions of juvenile rainbow trout fed with five different experimental diets for 7 weeks are summarized in Table 4. Moisture of fish fed $\mathrm{TBB}_{37.5}$ diet was significantly higher than $\mathrm{CON}, \mathrm{TBB}_{12.5}$, $\mathrm{TBB}_{25}$, and $\mathrm{TBB}_{50}$ diets. No significant differences were found among the fish fed $\mathrm{CON}, \mathrm{TBB}_{12.5}, \mathrm{TBB}_{25}$, and $\mathrm{TBB}_{50}$ diets. Crude protein of fish fed $\mathrm{CON}$ showed no significant differences among the fish fed every diets. But fish fed $\mathrm{TBB}_{12.5}, \mathrm{TBB}_{25}$, and $\mathrm{TBB}_{50}$ diets were significantly higher than fish fed $\mathrm{TBB}_{37.5}$ diet. No significant difference was founded in crude lipid and crude ash among the fish fed every diets.

\section{Hematological parameters}

Hematological parameters of blood serum in juvenile rainbow trout fed with five different experimental diets for 7 weeks are summarized in Table 5. Total protein of fish fed CON showed no significant differences $(P>0.05)$ among the fish fed all the experimental diets. But fish fed $\mathrm{TBB}_{12.5}$ diet was significantly higher $(P<0.05)$ than $\mathrm{TBB}_{37.5}$ and $\mathrm{TBB}_{50}$ diets. GOT of fish fed $\mathrm{TBB}_{25}, \mathrm{TBB}_{37.5}$, and $\mathrm{TBB}_{50}$ diets was significantly higher $(P<0.05)$ than fish fed CON diet. But fish fed CON and $\mathrm{TBB}_{12.5}$ diets showed no significant differences

Table 2 Growth performances of juvenile rainbow trout fed with five experimental diets for 7 weeks

\begin{tabular}{|c|c|c|c|c|c|}
\hline & \multicolumn{5}{|l|}{ Diets } \\
\hline & $\overline{\mathrm{CON}}$ & $\mathrm{TBB}_{12.5}$ & $\mathrm{TBB}_{25}$ & $\mathrm{TBB}_{37.5}$ & $\mathrm{TBB}_{50}$ \\
\hline$\overline{W G^{1}}$ & $259 \pm 14.9^{a}$ & $250 \pm 17.4^{\mathrm{ab}}$ & $243 \pm 17.7^{\mathrm{ab}}$ & $239 \pm 29.0^{\mathrm{ab}}$ & $225 \pm 8.82^{b}$ \\
\hline$S G R^{2}$ & $2.13 \pm 0.07^{a}$ & $2.09 \pm 0.08^{\mathrm{ab}}$ & $2.05 \pm 0.09^{\mathrm{ab}}$ & $2.03 \pm 0.14^{\mathrm{ab}}$ & $1.96 \pm 0.05^{b}$ \\
\hline $\mathrm{FE}^{3}$ & $133 \pm 6.14^{a}$ & $131 \pm 6.34^{\mathrm{ab}}$ & $127 \pm 1.30^{\mathrm{ab}}$ & $125 \pm 2.82^{\mathrm{ab}}$ & $125 \pm 1.88^{b}$ \\
\hline $\mathrm{PER}^{4}$ & $2.76 \pm 0.12^{\mathrm{a}}$ & $2.70 \pm 0.12^{\mathrm{ab}}$ & $2.63 \pm 0.03^{\mathrm{ab}}$ & $2.62 \pm 0.05^{\mathrm{ab}}$ & $2.59 \pm 0.04^{b}$ \\
\hline$\left.H S\right|^{5}$ & $1.07 \pm 0.50^{\text {ns }}$ & $0.91 \pm 0.15$ & $0.98 \pm 0.12$ & $1.03 \pm 0.15$ & $1.00 \pm 0.13$ \\
\hline$V S I^{6}$ & $6.58 \pm 0.67^{\mathrm{ab}}$ & $7.01 \pm 0.60^{\mathrm{ab}}$ & $6.87 \pm 1.13^{\mathrm{ab}}$ & $7.26 \pm 0.99^{a}$ & $6.35 \pm 0.53^{b}$ \\
\hline $\mathrm{CF}^{7}$ & $1.07 \pm 0.08^{\mathrm{a}}$ & $0.98 \pm 0.09^{b c}$ & $1.04 \pm 0.08^{\mathrm{ab}}$ & $0.98 \pm 0.06^{\mathrm{ab}}$ & $0.90 \pm 0.06^{c}$ \\
\hline$S R^{8}$ & $93.3 \pm 7.64^{\text {ns }}$ & $91.7 \pm 5.77$ & $91.7 \pm 7.64$ & $93.3 \pm 11.6$ & $95.7 \pm 2.89$ \\
\hline
\end{tabular}

Values are means from triplicate groups of fish $(n=3)$ where values in each row with different superscripts are significantly different $(P<0.05)$

${ }^{1}$ Weight gain $(W G)=($ final weight - initial weight $) \times 100 /$ initial weight

${ }^{2}$ Specific growth rate $(S G R ; \% /$ day $)=($ In final weight - In initial weight $) \times 100 / d$

${ }^{3}$ Feed efficiency $(\mathrm{FE} ; \%)=$ wet WG $(\mathrm{g}) \times 100 /$ dry feed intake $(\mathrm{g})$

${ }^{4}$ Protein efficiency ratio $(\mathrm{PER})=$ wet weight gain/protein intake

${ }^{5}$ Hepatosomatic index $(\mathrm{HSI} ; \%)=$ (liver weight/body weight $) \times 100$

${ }^{6}$ Viscerosomatic index (VSI; \%) $=$ (visceral weight/body weight $) \times 100$

${ }^{7}$ Condition factor $(\mathrm{CF})=\left\{\right.$ fish weight $(\mathrm{g}) /$ fish length $\left.(\mathrm{cm})^{3}\right\} \times 100$

${ }^{8}$ Survival $($ SR; \%) $=$ (total fish-dead fish) $\times 100 /$ total fish 


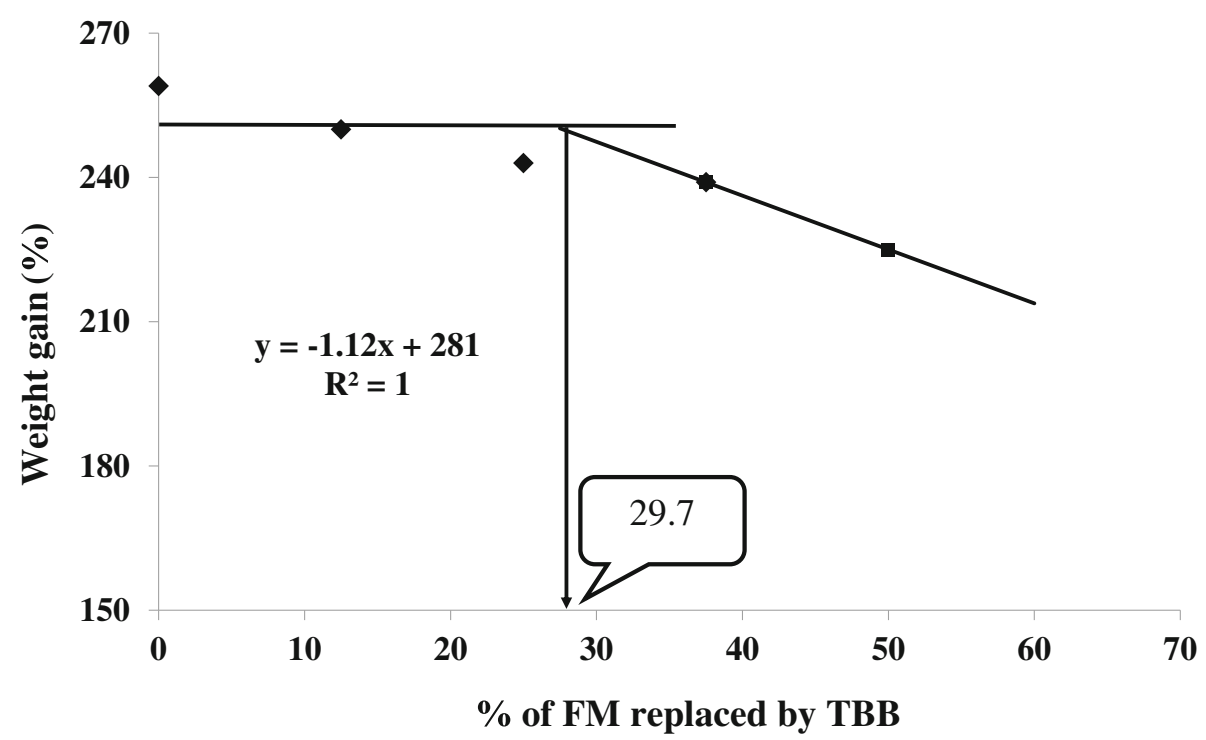

Fig. 1 Broken line regression analysis of weight gain in rainbow trout fed experimental diets at different TBB levels

$(P>0.05)$. GPT of fish fed $\mathrm{TBB}_{50}$ was significantly higher $(P<0.05)$ than the other diets. But no significant difference $(P>0.05)$ was observed among fish fed CON, $\mathrm{TBB}_{12.5}, \mathrm{TBB}_{25}, \mathrm{TBB}_{37.5}$ and $\mathrm{TBB}_{50}$.

\section{Discussion}

In this study, enzymatically hydrolyzed tuna backbone by-product was used in different levels in experimental diets to partially replace commercially used fish meal (FM). After completion of the feeding trial, weight gain (WG) and specific growth rate (SGR) of fish fed the $37.5 \%$ replacement diets with tuna backbone by-product were not significantly different from the FM fed fish. Although, 50\% replacement of FM with tuna backbone by-product reduced both the WG and SGR. This indicates that enzymatic hydrolyzed tuna backbone by-product containing diets can partially replace FM but up to at a certain level. In a relevant study by Mendoza et al. (2001), it was reported that using enzymatic hydrolyzed and co-extruded feather meal with soya-bean meal in practical diets for the pacific-white shrimp (Litopenaeus vannamei) can replace up to $20 \%$ of FM without

Table 3 Non-specific immune responses of juvenile rainbow trout fed with five experimental diets for 7 weeks

\begin{tabular}{llllll}
\hline & \multicolumn{5}{l}{ Diets } \\
\cline { 2 - 6 } & CON & $\mathrm{TBB}_{12}$ & $\mathrm{TBB}_{25}$ & $\mathrm{TBB}_{37}$ & $\mathrm{TBB}_{50}$ \\
\hline Lys $^{1}$ & $1.35 \pm 0.30^{\text {ns }}$ & $1.58 \pm 0.32$ & $1.60 \pm 0.28$ & $1.64 \pm 0.37$ & $1.24 \pm 0.05$ \\
SOD $^{2}$ & $80.9 \pm 8.27^{\text {ns }}$ & $79.0 \pm 7.76$ & $80.6 \pm 4.09$ & $76.4 \pm 2.02$ & $83.6 \pm 7.07$
\end{tabular}

Values are means from triplicate groups of fish $(n=3)$ where in each row with different superscripts values are significantly different $(P<0.05)$

'Lysozyme (U/I)

${ }^{2}$ Superoxide dismutase (\% inhibition) reducing growth performance and body composition. Feed utilization performance parameters such as FE and PER were also influenced by dietary treatments in this study. FE and PER were both similar in fish fed the $\mathrm{CON}$ diet and those of fish fed diets replacing up to $37.5 \%$ of fish meal with tuna backbone by-product. Higher replacement levels $\left(\mathrm{TBB}_{50}\right)$ decreased FE and PER in rainbow trout. This indicates that up to $37.5 \%$ of FM replacement by tuna backbone by-product did not negatively influence feed utilization performance of rainbow trout. These results were consistent with the observations in studies that used combinations of various protein sources in the diets of rainbow trout (Jo et al. 2016; Bureau et al. 2000). Similar studies on rainbow trout have also reported that partially hydrolyzed ingredients have higher nutritional value because of higher

Table 4 Whole body proximate composition of juvenile rainbow trout fed with five experimental diets for 7 weeks (\% dry matter basis)

\begin{tabular}{llllll}
\hline & \multicolumn{5}{l}{ Diets } \\
\cline { 2 - 6 } & $\mathrm{CON}$ & $\mathrm{TBB}_{12.5}$ & $\mathrm{TBB}_{25}$ & $\mathrm{TBB}_{37.5}$ & $\mathrm{TBB}_{50}$ \\
\hline $\mathrm{Mo}^{1}$ & $78.3 \pm 0.11^{\mathrm{b}}$ & $77.2 \pm 0.58^{\mathrm{b}}$ & $78.3 \pm 0.22^{\mathrm{b}}$ & $79.1 \pm 0.32^{\mathrm{a}}$ & $78.3 \pm 0.47^{\mathrm{b}}$ \\
$\mathrm{CP}^{2}$ & $14.6 \pm 0.45^{\mathrm{ab}}$ & $15.1 \pm 0.25^{\mathrm{a}}$ & $15.1 \pm 0.02^{\mathrm{a}}$ & $14.4 \pm 0.07^{\mathrm{b}}$ & $15.2 \pm 0.56^{\mathrm{a}}$ \\
$\mathrm{CL}^{3}$ & $4.80 \pm 0.75^{\mathrm{ns}}$ & $5.06 \pm 0.52$ & $5.26 \pm 0.06$ & $4.60 \pm 0.20$ & $4.93 \pm 0.44$ \\
$\mathrm{As}^{4}$ & $1.94 \pm 0.10^{\mathrm{ns}}$ & $2.06 \pm 0.10$ & $1.96 \pm 0.10$ & $1.92 \pm 0.05$ & $2.10 \pm 0.16$ \\
\hline
\end{tabular}

Values are means from triplicate groups of fish $(n=3)$ where in each row with different superscripts values are significantly different $(P<0.05)$

${ }^{1} M o$ moisture content of whole body composition of juvenile rainbow trout in different diets

${ }^{2} \mathrm{CP}$ crude protein present under different dietary treatments

${ }^{3} \mathrm{C}$ crude lipid, present in whole body proximate composition of juvenile rainbow trout after feeding trial

${ }^{4}$ As ash content of whole body proximate composition of fish in different diets 
Table 5 Hematological parameters of juvenile rainbow trout fed with five experimental diets for 7 weeks

\begin{tabular}{llllll}
\hline & Diets & & & \\
\cline { 2 - 5 } & CONT & $\mathrm{TBB}_{12.5}$ & $\mathrm{TBB}_{25}$ & $\mathrm{TBB}_{37.5}$ & $11.3 \pm 6.03$ \\
\hline $\mathrm{GL}^{1}$ & $105 \pm 6.51^{\mathrm{ns}}$ & $112 \pm 8.19$ & $113 \pm 3.00$ & $3.30 \pm 0.10^{\mathrm{b}}$ & $107 \pm 9.17$ \\
$\mathrm{TP}^{2}$ & $3.60 \pm 0.10^{\mathrm{ab}}$ & $3.73 \pm 0.23^{\mathrm{a}}$ & $3.40 \pm 0.26^{\mathrm{ab}}$ & $3.33 \pm 0.25^{\mathrm{b}}$ \\
$\mathrm{GOT}^{3}$ & $402 \pm 39.1^{\mathrm{c}}$ & $452 \pm 26.0^{\mathrm{bc}}$ & $517 \pm 16.2^{\mathrm{ab}}$ & $530 \pm 52.9^{\mathrm{a}}$ & $509 \pm 44.5^{\mathrm{ab}}$ \\
$\mathrm{GPT}^{4}$ & $8.00 \pm 3.61^{\mathrm{b}}$ & $8.67 \pm 2.08^{\mathrm{b}}$ & $10.3 \pm 2.31^{\mathrm{b}}$ & $10.0 \pm 1.73^{\mathrm{b}}$ & $18.7 \pm 2.52^{\mathrm{a}}$ \\
\hline
\end{tabular}

Values are means from triplicate groups of fish $(n=3)$ where in each row with different superscripts values are significantly different $(P<0.05)$

${ }^{1} G L$ glucose (mg/dl)

${ }^{2} T P$ total protein $(\mathrm{g} / \mathrm{d})$

${ }^{3} \mathrm{GOT}$ glutamic glutamic oxaloacetic transaminase (U/)

${ }^{4} G P T$ glutamic pyruvic transaminase (U/l):

levels of free amino acids. This makes these ingredients more digestible and fish can utilize the ingredients more efficiently that will results in higher growth and feed utilization performances (Dong et al. 1993; Hardy 2002). The hepatosomatic index (HSI) was not changed in fish fed all the experimental diets. Although, viscerosomatic index (VSI) and condition factor (CF) were lower in fish fed the TBB50 diet compared to those of fish fed the CON diet. HIS, VSI, and CF are good representatives for health, general well-being, and feed quality (Ighwela et al. 2014). These parameter showed that until 37.5\% replacement of FM with tuna backbone by-product has no negative effects on rainbow trout organosomatic health. These results were similar with previous studies using tuna by-products as a protein source for rainbow trout (Samuelsen et al. 2001; Caballero et al. 2002; Tekinay et al. 2009). Noteworthy, in this study, we observed more than $90 \%$ survival for all experimental groups that could be related to standard rearing condition and feed. Whole body proximate composition of rainbow trout fed the experimental diets did not show any specific trend in the present study. Whereas crude lipid and ash were same for all fish fed the experimental diets and there were no significant differences in crude protein between the $\mathrm{CON}$ and other experimental groups. Some studies have reported a trend in which whole body moisture content shows opposite values compared to protein content in rainbow trout, O. mykiss (Jo et al. 2016); kuruma shrimp, Marsupenaeus japonicas (Bulbul et al. 2016); and Australian short-finned eel, Aaustralis australis (Engin and Carter 2005).

Non-specific immune responses are the basic mechanism of defense system in fish and play a vital role in the obtained immune response and homeostasis by a system of receptor proteins (Srivastava and Pandey 2015; Halver and Hardy 2002; Reverter et al. 2014; Uribe et al. 2011). Lysozyme activity is an important humoral indicator of non-specific immunity in fish and one of the important enzymes of defensive mechanism that protects the host (Ellis 1999; Jo et al. 2016). On the other hand, SOD is a metalloenzyme that catalyzes the superoxide radical
$\left(\mathrm{O}_{2-}\right)$ dismutation into molecular oxygen $\left(\mathrm{O}_{2}\right)$ and hydrogen peroxide $\left(\mathrm{H}_{2} \mathrm{O}_{2}\right)$ (Shao et al. 2010). This will support a significant defense system against oxidative damage. Findings of the present study did not show any significant differences in lysozyme or SOD activities in all the experimental fish. This shows that even 50\% replacement of FM with tuna backbone by-product does not influence the innate immunity of rainbow trout. This could be attributed to standard experimental conditions while tuna backbone by-product was providing sufficient protein with well-balanced amino acids to support the immune system (Sullivan 2008; Jo et al. 2016).

Serum parameters as well as hematological activities are good indicators of health status of any organism and can vary with temperature, season, and nutritional status (Blaxhall 1972). They are suitable indicators for evaluating the health, stress level, and physiological welfare of fish (Simide et al. 2016). Serum glucose is a stress indicator of fish and stress hormone which is associated with cortisol, mobilize and increase glucose production in blood serum to cope with the required energy produced by a stressor (Wallace et al. 1994). Total protein of blood serum is also considered a strong natural response in fish (Reverter et al. 2014) and assessments can reflect nutritional levels. (Acharya and Mohanty 2014). In the present study, glucose content of serum did not show any significant differences in fish fed all the experimental diets. There were also no differences in serum total protein level of fish fed the CON diet and those of fish fed the other diets. Glutamic oxaloacetic transaminase (GOT) and glutamic pyruvic transaminase (GPT) which are enzymes or proteins mostly found in liver cells and rising levels in blood serum indicate damage or inflammation of liver cells (Giannini et al. 2005). In the present study, the GOT level showed an increasing trend with higher FM replacement levels. While fish fed diets $\mathrm{TBB}_{25}, \mathrm{TBB}_{37.5}$, and $\mathrm{TBB}_{50}$ had a higher GOT compared to fish fed the CON diet. Serum GPT also showed higher levels for fish fed the $\mathrm{TBB}_{50}$ diet compared to all other experimental fish. An increase in GOT and GPT could be attributed to the addition of alternative protein 
sources in fish diets because of various dynamics such as reduction in FM content, tolerance of anti-nutritional factors, digestibility, and palatability problems (Jo et al. 2016; National Research Council, NRC 2011).

\section{Conclusions}

Considering growth performances, non-specific immune responses, other relevant parameters in $\mathrm{CON}$, and other diets which included tuna backbone by-products for FM replacement, the present study demonstrated that FM can be replaced greater than $29.7 \%$ but less than $37.5 \%$ by enzymatically hydrolyzed tuna backbone by-products in the diets of juvenile rainbow trout. The findings of the study will also encourage the feed manufacturers to utilize enzymatically hydrolyzed tuna backbone by-products as alternative protein sources in generating low-cost and healthy aqua feed.

\section{Acknowledgements}

This study was conducted by support of Pukyong National University Research Fund in 2017 (C-D-2017-0333) and Corporation the Feeds \& Foods Nutrition Research Center (FFNRC).

\section{Funding}

This research work was supported by the Pukyong National University Research Fund in 2017 (C-D-2017-0333).

\section{Availability of data and materials}

Please contact author for data requests.

\section{Authors' contributions}

JB designed, conducted the experiment, and wrote the paper. MDAKA conducted feeding trial. SW design and conducted some parts of the analysis and experiment. AH prepared of the ingredients and feeding trial. MS conducted analysis of sample. SCB supervised the experiment. All authors read and approved the final manuscript.

\section{Ethics approval and consent to participate}

This research work was supported by Feeds and Foods Nutrition Research Center (FFNRC), Pukyong National University, Busan, Rep. of Korea. The study was conducted under the guidelines of the Ethics in Animal Research (Animal Ethics Committee Regulations, No. 17-0246).

\section{Consent for publication}

Not applicable.

\section{Competing interests}

The authors declare that they have no competing interests.

\section{Publisher's Note}

Springer Nature remains neutral with regard to jurisdictional claims in published maps and institutional affiliations.

\section{Author details}

${ }^{1}$ Department of Marine Bio-Materials and Aquaculture/Feeds and Foods Nutrition Research Center (FFNRC), Pukyong National University, 599-1 Daeyeon 3-Dong, Busan 608-737, Republic of Korea. ${ }^{2}$ Upazila Fisheries, Rajshahi, Mohanpur, Bangladesh.
Received: 11 November 2018 Accepted: 4 January 2019

Published online: 22 January 2019

\section{References}

Acharya G, Mohanty PK. Comparative haematological and serum biochemical analysis of catfishes Clariasbatrachus (Linnaeus, 1758) and Heteropneustes fossilis (Bloch, 1794) with respect to sex. J Entomol Zool Stud. 2014;2:191-7.

Anderson AD, Alam MS, Watanabe WO, Carroll PM, Wedegaertner TC, Dowd MK. Full replacement of menhaden fish meal protein by low-gossypol cottonseed flour protein in the diet of juvenile black sea bass, Centropristis striata. Aquaculture. 2016:464:618-28.

AOAC. (Association of Official Analytical Chemists). Official methods of analysis. 18th ed. Gaithersburg: Association of Official Analytical Chemists; 2005.

Baek HH, Cadwallader KR. Enzymatic hydrolysis of crayfish processing byproducts. J Food Sci. 1995:60:929-35.

Berthelot C, Brunet F, Chalopin D, Juanchich A, Bernard M, Noel B, Guiguenk Y. The rainbow trout genome provides novel insights into evolution after whole-genome duplication in vertebrates. Nat Commun. 2014;5:3657.

Blaxhall PC. The haematological assessment of the health of freshwater fish. J Fish Biol. 1972:4:593-604

Boyle D, Al-Bairuty GA, Ramsden CS, Sloman KA, Henry TB, Handy RD. Subtle alterations in swimming speed distributions of rainbow trout exposed to titanium dioxide nanoparticles are associated with gill rather than brain injury. Aquat Toxicol. 2013;126:116-27.

Bulbul M, Kader MA, Asaduzzaman M, Ambak MA, Chowdhury AJK, Hossain MS, Ishikawa M, Koshio S. Can canola meal and soybean meal be used as major dietary protein sources for kuruma shrimp, Marsupenaeus japonicus. Aquaculture. 2016;452:194-9.

Bureau DP, Harris AM, Bevan DJ, Simmons LA, Azevedo PA, Cho CY. Feather meals and meat and bone meals from different origins as protein sources in rainbow trout, Oncorhynchus mykiss. Aquaculture. 2000;181:281-91.

Caballero MJ, Obach A, Rosenlund G, Montero D, Gisvold M, Izquierdo MS. Impact of different dietary lipid sources on growth, lipid digestibility, tissue fatty acid composition and histology of rainbow trout, Oncorhynchus mykiss. Aquaculture. 2002;214:253-71.

Cho JH, Kim IH. Fish meal-nutritive value. J Anim Physiol An N. 2011;95:685-92.

Cowey CB. Nutrition: estimating requirements of rainbow trout. Aquaculture. 1992;100:177-89.

Dong FM, Hardy RW, Haard NF, Barrows FT, Rasco BA, Fairgrieve WT, Forster IP. Chemical composition and digestibility of poultry by-product meals for salmon diets. Aquaculture. 1993;116:149-58.

Ellis AE. Immunity to bacteria in fish. Fish Shellfish Immun. 1999;9:291-308.

Engin K, Carter CG. Fish meal replacement by plant and animal byproductsin diets for the Australian short-finned eel, Anguilla australis (Richardson). Aquac Res. 2005;36:445-54.

FAO 2018 Global aquaculture production database updated to 2016 [http:// www.fao.org/fishery/statistics/en] Accessed on date 4 NOV 2018.

Forster I, Bechtel P, Dominy WG, Lane S, Avena R, Ju ZY, Conquest L. (2011). Use of fish hydrolysates and fish meal byproducts of the Alaskan fishing industry in diets for Pacific white shrimp Litopennaeus vannamei. N AM J Aquacult. 2011;73:288-95.

Giannini EG, Testa R, Savarino V. 2005. Liver enzyme alteration: a guide for clinicians. Can Med Assoc J. 2005:172:367-79.

Halver JE, Hardy RW. Fish nutrition: academic press; 2002.

Hardy RW. Rainbow trout: (Oncorhynchus mykiss). In: Webster CD, Lim CE, editors. In nutrient requirements and feeding of finfish for aquaculture. 1st ed: CABI Publishing; 2002. p. 184-202.

Hauptman BS, Barrows FT, Block SS, Gaylord TG, Paterson JA, Rawles SD, Sealey WM. Evaluation of grain distillers dried yeast as a fish meal substitute in practical-type diets of juvenile rainbow trout, Oncorhynchus mykiss. Aquaculture. 2014;432:7-14.

Hultmark D. Insert immunity: purification and properties of three inducible bactericidal proteins from hemolymph of immunized pupae of Hyalophora cecropia. Eur J Biochem. 1980;106:7-16.

IFFO. 2018. International fish meal and fish oil organization.

Ighwela KA, Ahmad AB, Abol-Munafi AB. The selection of viscerosomatic and hepatosomatic indices for the measurement and analysis of Oreochromis niloticus condition fed with varying dietary maltose levels. Int J Faun Biolog. 2014;1:18-20.

Je JY, Qian ZJ, Byun HG, Kim SK. Purification and characterization of an antioxidant peptide from tuna backbone protein by enzymatic hydrolysis. Process Biochem. 2007;42(5):840-6. 
Jo H, Lee S, Yun H, Hong J, Moniruzzaman M, Bai SC, Jeon TE. Evaluation of dietary fishmeal analogue with addition of shrimp soluble extract on growth and nonspecific immune response of rainbow trout, Oncorhynchus mykiss. J World Aqua Soc. 2016;48(4):583-91.

KOSTAT. Korean Statistics 2018 [www.fips.go.kr] Accessed on date 3 NOV 2018.

Leblanc EL, Gill TA. Comparative study of proteolysis in short-finned (Illex illecebrosus) and long-finned (Loligo pealeileseur) squid. Comp Biochem and Phys B. 1982;73(2):201-10.

Lian PZ, Lee CM, Park E. Characterization of squid processing by-product hydrolysates and its potential as aquaculture feed ingredient. J Agr Food Chem. 2005;53(14):5587-92

Liaset B, Lied E, Espe M. Enzymatic hydrolysis of byproducts from the fish-filleting industry; chemical characterization and nutritional evaluation. J Sci Food Agr. 2000;80(5):581-9.

Masumoto T, Tamura B, Shimeno S. Effects of phytase on bioavailability of phosphorus in soybean meal-based diets for Japanese flounder, Paralichthys olivaceus. Fish Sci. 2001;210:359-69.

Mendoza R, Dios A, Vazquez C, Cruz E, Ricque DC, Aguilera C, Montemayor J. Fishmeal replacement with feather-enzymatic hydrolysates co-extruded with soya-bean meal in practical diets for the pacific-white shrimp (Litopenaeus vannamei). Aquaculture Nut. 2001;7(3):143-51.

National Research Council, NRC. Nutrient requirements of fish and shrimp. National Research Council: National Academy Press; 2011.

Nielsang S, Lertsiri S, Suphantharika M, Assavanig A. Optimization of enzymatic hydrolysis of fish soluble concentrate by commercial proteases. J Food Eng. 2005;70(4):571-8.

Panyam D, Kilara A. Enhancing the functionality of food proteins by enzymatic modification. Trends Food Sci Tech. 1996;7(4):120-5.

Papatryphon E, Soares JH Jr. The effect of phytase on apparent digestibility of four practical plant feedstuffs fed to striped bass, Moronesaxatillis. Aqua. Nut. 2001;7:161-7.

Reverter M, Bontemps N, Lecchini D, Banaigs B, Sasal P. Use of plant extracts in fish aquaculture as an alternative to chemotherapy: current status and future perspectives. Aquaculture. 2014;433:50-61.

Rodger G, Weddle RB, Carig P, Hastings R. Effect of alkaline protease activity on some properties of comminuted squid. J Food Sci. 1984;49(1):117-23.

Samuelsen T, Isaksen M, McLean E. Influence of dietary recombinant microbial lipase on performance and quality characteristics of rainbow trout (O. mykiss). Aquaculture. 2001;194:161-71.

Shao XP, Liu WB, Xu WN, Lu KL, Xia W, Jiang YY. Effects dietary copper sources and levels on performance, copper status, plasma antioxidant activities and relative copper bioavailability in Carassius auratus gibelio. Aquaculture. 2010; 308:60-5

Simide R, Richard S, Prévot-D'Alvise MT, Gaillard S. Assessment of the accuracy of physiological blood indicators for the evaluation of stress, health status and welfare in Siberian sturgeon, Acipenser baeri. Int Aqua Res. 2016;8(2):121-35.

Srivastava PK, Pandey AK. Role of immunostimulants in immune responses of fish and shellfish. Biochem Cell Arch. 2015;15(1):47-73.

Sugiyama M, Kousu S, Hanabe M, Okuda Y. In: Sugiyama M, Kousu S, Hanabe M, Okuda Y, editors. Chemical properties: utilization of squid. New Dheli: Oxonian Press; 1989. p. 251

Sullivan KB. Replacement of fish meal by alternative protein sources in diets for juvenile black sea bass. PhD thesis. University of North Carolina Wilmington: Department of Biology and Marine Biology; 2008.

Tekinay AA, Deveciler E, Guroy D. Effects of dietary tuna by-products on feed intake and utilization of rainbow trout, Oncorhynchus mykiss. J Fisheries Int. 2009;4(1):8-12

Thorgaard GH, Bailey GS, Williams D, Buhler DR, Kaattari SL, Ristow SS, Paltik Y Status and opportunities for genomics research with rainbow trout. Comp Biochem Phys B. 2002;133(4):609-46.

Tomas A, Gandara FDL, Garcia-Gomez A, Perez L, Jover M. Utilisationof soybean meal as an alternative protein source in the Mediterranean yellowtail, Seriola dumerili. Aqua Nut. 2005;11:333-40.

Uribe C, Folch H, Enriquez R, Moran G. Innate and adaptive immunity in teleost fish: a review. Veterinarni Medicina. 2011;56(10):486-503.

Uyan O, Koshio S, Teshima S, Ishikawa M, Thu M, Alam MS, Michael FR. Growth and phosphorous loading by partially replacing fishmeal with tuna muscle by-product powder in the diet of juvenile Japanese flounder, Paralichthys olivaceus. Aquaculture. 2006:257:437-45.
Vehviläinen $H$, Kause A, Quinton C, Koskinen $H$, Paananen T. Survival of the currently fittest: genetics of rainbow trout survival across time and space. Genetics Soc America. 2008;180:507-16.

Wallace RJ, Arthaud L, Newbold CJ. Influence of Yucca schidigera extract on ruminal ammonia concentrations and ruminal microorganisms. Appl Environ Microbiol. 1994;60:1762-7.

Weerd JHV, Khalaf KHA, Aalen FJ, Tijsses PA. Balance trials with African catfish Clarias gariepinus fed phytase-treated soybean meal-based diets. Aqua Nut. 1999:5:135-14.

\section{Ready to submit your research? Choose BMC and benefit from:}

- fast, convenient online submission

- thorough peer review by experienced researchers in your field

- rapid publication on acceptance

- support for research data, including large and complex data types

- gold Open Access which fosters wider collaboration and increased citations

- maximum visibility for your research: over $100 \mathrm{M}$ website views per year

At BMC, research is always in progress.

Learn more biomedcentral.com/submissions 